DOI: 10.31392/NPU-nc.series14.2019.27.03

УДК $37.06+378.013+378.147$

Линенко А. Ф., Ніколаї Г. Ю., Левицька І. М.

\title{
Методичний супровід художньо-естетичного контенту виконавської підготовки майбутніх учителів музичного мистецтва
}

У статті актуалізовано проблему методичного забезпечення музично-виконавської підготовки майбутніх учителів музичного мистецтва в контексті її художньо-естетичного, педагогічного потенціалу. Виконавська підготовка представлена у комплексі вокальної, фортепіанної та диригентсько-хорової складових. Визначено методологічні підходи, принципи, методи, що складають методичний супровід художньо-естетичної якості різних видів виконавської підготовки. Акцентовано увагу на гармонійності емоційного та когнітивного психологічних процесів, що формує емоційно-когнітивний досвід майбутніх учителів музичного мистецтва. Він стає фаховим чинником якісної інтерпретації музичних творів відповідно до їх художньо-естетичного контенту. Визначено його педагогічні вектори.

Ключові слова: музично-виконавська підготовка; вокальна підготовка; диригентсько-хорова підготовка; емоційно-когнітивний досвід; майбутні вчителі музичного мистецтва.

Актуальність дослідження. Виконавська підготовка майбутніх учителів музичного мистецтва $є$ обов'язковою складовою фахового блоку цілісної професіональної системи підготовки фахівців напряму 014 Середня освіта (Музичне мистецтво). Вона забезпечує комплекс фахових компетентностей музично-виконавського змісту відповідно до першого (бакалаврського) та другого (магістерського) рівнів вищої освіти. Зокрема до першого (бакалаврського) рівня актуальною, відповідно до виконавської підготовки, стає така компетентність як здатність до фахового художньо-педагогічного самовдосконалення в процесі освоєння навчальних програм музично-виконавських дисциплін (основний музичний інструмент, постановка голосу, хорове диригування) в процесі інтерпретації музичних творів.

Нерідко художній контент виконавської підготовки не знаходить повного та осмисленого втілення в освітній процес. Це пояснюється тим, що до навчання поступають абітурієнти 3 низьким рівнем попередньої фахової підготовки. Уже на другому (магістерському) рівні, коли набуто певних виконавських умінь та навичок, постає питання умінь глибокого занурення в художньо-естетичний світ музичних творів 3 метою їх якісної інтерпретації та здатності застосувати їх художньо-естетичний потенціал в роботі зі школярами. Але терміну навчання на магістерському рівні для якісної художньо-ціннісної інтерпретації музичних творів не вистачає. Таким чином, постає питання постійного методичного супроводу художньо-естетичного контенту виконавської підготовки майбутніх учителів музичного мистецтва, починаючи 3 перших курсів навчання у ЗВО. Зазначене актуалізує проблему уточнення смислу художньо-естетичного контенту виконавської підготовки майбутніх учителів музичного мистецтва та розробки методичного супроводу його реалізації.

Проблема художньо-естетичного контенту виконавської підготовки майбутніх учителів музичного мистецтва грунтується на засадах методичної спадщині та рекомендацій провідних музикантів, зокрема у фортепіанному виконавстві - К.Ггумнов, С.Майкапар, Г.Нейгауз, С. Савшинський та ін., у вокальному - В.Антонюк, В.Багадуров, М.Глинка, Л.Дмитрієв, Ф.Ламперті, В.Морозов; у диригентсько-хоровому - О.Кошиць, О.Леонтович, К.Пігров та ін. Методична спадщина багатьох музикантів відрефлексована науковцями у галузі музикознавства. Зокрема в працях М.Воротного [3] проаналізовано методичну спадщину С.Савшинського, який вказував на естетичний та художній аспекти виконавства. Я.Мільштейн [11] здійснив глибокий аналіз методичної спадщини Ф.Шопена, та ін. Методична спадщина К.Черні, Ф.Листа, Ф.Шопена, їх педагогічні принципи стали предметом дослідження О. Кірчанової [6], яка здійснила своє дослідження у галузі музичної педагогіки.

Художній контент виконавського процесу у сучасній науково-педагогічній літературі щодо вокальної підготовки представлений з різних поглядів. Так, художньо-виконавський аспект у вокальній підготовці представлено у доробках А.Ткачук [15], Чжан Яньфена [18], 
ідеї художньо-комунікативного процесу - у дослідженні Мен Сіана [10], творчо-виконавська взаємодія - у дослідженні Лай Сяоцянь [7], артистизм - у дослідженні Ван Ченя [2]. Художньо-комунікативний, полікультурний контент диригентської підготовки висвітлено у дослідженні Ван Яцзюня [20].

Різні аспекти фортепіанного виконавства, що мають забезпечити його художньоестетичний контекст, представлено у доробках та дослідженнях Бай Біня [1], який розкриває художньо-естетичний ресурс звуко-тембральних уявлень піаніста; Лі Ює [8], яка досліджує феномен художньо-смислових уявлень; М.Демір, яка досліджує інтерпретаційну культуру майбутніх учителів музики [4]. Технологічні аспекти посилення художньої інтерпретації фортепіанних творів розглядаються крізь призму норативної педагогіки у доробку О.Олексюк та О.Ребрової [19]. Безпосередньо естетичний аспект виконавської підготовки представлено у дослідженні Цзяо Їн [17].

Незважаючи на широкий спектр представлених досліджень щодо художньо-естетичних аспектів музичного виконавства, цілісного уявлення про методичний супровід художньоестетичного контенту виконавської підготовки майбутніх учителів музичного мистецтва бракує.

Мета статті полягає у вибудувані методичного супроводу художньо-естетичного контенту виконавської підготовки майбутніх учителів музичного мистецтва з урахуванням основних векторів іiї педагогічної спрямованості та усіх фахових різновидів. Для досягнення поставленої мети доцільно уточнити поняття «методичний супровід», «виконавська підготовка»; визначити сутність їх художньо-естетичного контенту; окреслити основні педагогічні завдання, на які спрямована музично-виконавська (вокальна, фортепіанна, диригентсько-хорова) підготовка майбутніх учителів музичного мистецтва з урахуванням іiі художньо-естетичного потенціалу. Зазначене складає завдання теоретико-методичного дослідження.

Виклад основного матеріалу. Застосування методів категоріального аналізу та теоретичного узагальнення дозволило уточнити сутність ключових понять, зокрема «художньо-естетичний контент» виконавської підготовки. Так, згідно методики С.Савшинського щодо феноменології художнього та естетичного у фортепіанному виконавстві, існує три аспекти: художній, естетичний та технічний. К.Завалко їх пояснює таким чином: художній - «проникливість, змістовність, артистичність та емоційність, шляхетність та виразність інтонації»; естетичний - «темброве та динамічне багатство звучання»; технічний - «високий ступень майстерності, віртуозність виконання» [5, с. 104].

М.Воротний аналізує етапи еволюції фортепіанного виконавства та його методичного забезпечення; він вказує на важливість саме останнього погляду піаністів-педагогів, згідно якому «... розвиток виконавської майстерності зв'язаний, у першу чергу, з вихованням музичних уподобань, художньої уяви, волі, уваги». А подолання технічних труднощів може бути здійснено за рахунок аналітичної роботи та накопичення саме художнього репертуару [3].

Цзяо Їн визначає сутність художньо-естетичної спрямованості фортепіанної підготовки майбутнього вчителя музики таким чином. Це «...процес і результат досягнення якісного рівня різноманітних функцій фортепіанного виконавства, котрий забезпечує вчителю ефективне використання інтерпретації художніх образів музичних творів, їх зв'язків з іншими видами мистецтва 3 метою художньо-естетичного розвитку учнів на засадах культуровідповідності» [17, с. 112].

Чжан Яньфен надає визначення поняттю «вокальна художньо-виконавська підготовка майбутнього вчителя музики» [18]. По-перше, це процес, що повністю співпадає з сутністю фахової підготовки як такої. Метою цієї підготовки $є$ «...формування біфункціонального художньо-синтезованого виконавського комплексу, спрямованого на реалізацію поліхудожнього і полімодального ресурсу вокального мистецтва в музично-педагогічному процесі на основі засвоєння художньо-культурних детермінант і особливостей вокальної 
творчості, художнього самовираження, оволодіння вокальним голосом i художньовиконавськими засобами інших видів мистецтва, фахової умотивованості особистості вчителя на реалізацію музично-розвиваючої і художньо-естетичної функцій вокального мистецтва в музично-освітньому процесі» $[18$, с. 16$]$.

Феноменологію «художнього» завжди розглядають у контексті мистецького синтезу, але це може бути розглянуто і відповідно до виконавського процесу. I тут художність у виконавстві несинтезованих видів мистецтва, наприклад, музично-інструментального виконавства, може бути розглянута як вищий рівень інтерпретації, яка викликає саме художні асоціації, аналогії з іншими видами мистецтва, з життєвими реаліями тощо.

Художньо-естетичний контент виконавської підготовки ми розглядаємо як процес опанування, осмислення та відтворення під час інтерпретації художньої інформації, що представлена у кожному музичному творі і має спрямований естетично-смисловий характер.

Методичний супровід ми розуміємо як цілеспрямоване постійне застосування комплексу методичних ресурсів, що забезпечують послідовну результативність освітнього процесу. Методичним супроводом художньо-естетичного контенту виконавської підготовки майбутніх учителів музичного мистецтва стають педагогічні ресурси, до яких можна віднести принципи, що відповідають актуальним методологічним підходам, методи, що спонукають розвиток художніх уявлень та умови і створюють атмосферу діалогу (культур, особистостей, творчої взаємодії), а також послідовне засвоєння студентами художньо-естетичного розвивального потенціалу видів виконавської творчості та різних стилів і жанрів музичних творів. Останні мають педагогічний потенціал у вирішенні завдань художньо-естетичного розвитку школярів, якій має бути усвідомлений майбутніми учителями музичного мистецтва під час інтерпретації вокальних, фортепіанних, хорових творів.

У процесі огляду наукових джерел щодо художньо-естетичної проблематики виконавської підготовки майбутніх учителів музичного мистецтва було звернено увагу на перевагу зазначеної дослідницької проблематики у молодих вчених з Китаю. Цей факт можна пояснити наступними чинниками: 1) традиційній переваги щодо технічного аспекту виконавської підготовці, як фортепіанної, так і вокальної у практиці підготовки майбутніх учителів музики у Китаї; 2) слабкою попередньою фаховою підготовкою, що впливає на якість навчання китайських студентів; 3)тяжіння до засвоєння мистецтва інокультурного походження за відсутністю відповідної до цього художньо-полікультурної компетентності.

Зазначені чинники впливають на зацікавлене ставлення дослідників 3 Китаю до проблематики художньо-естетичного контенту різних видів музично-виконавської підготовки. Це актуалізує застосування полікультурного та компаративістського підходу як методологічної основи дослідження художньо-естетичного контенту музично-виконавської підготовки майбутніх учителів музичного мистецтва.

Полікультурна та компаративістська методологія стає дедалі актуальнішою 3 урахуванням входження системи освіти України до європейського вектору розвитку освітньої галузі. Окрім того, саме мистецтво є відображенням цінностей та художньо-світоглядних позицій різних народів, держав, етносів тощо. Народне мистецтво історично впливало на професійне, що знаходило відображення в композиторській творчості та впливало на музично-педагогічну стратегію. Так, наприклад, виникали вокальні школи (італійська, російська, німецька, французька, китайська).

Стосовно фортепіанної підготовки також полікультурна методологія $€$ актуальною, оскільки кожний фортепіанний твір народжується під впливом культурних традицій, історичних подій, зумовлених пануючими художньо-естетичними уявленнями, що впливали на художній світогляд композитора. Через композиторську творчість, особливий художньообразний мисленнєвий стрій, його осмислення виконавцями, формуються уявлення щодо виконавської інтерпретації твору мистецтва. Таким чином, полікультурна методологія стає грунтом інтерпретаційної музично-виконавської культури. На це вказують дослідники О. Реброва та О. Олексюк [12], У Іфан [16] та ін. Так, наприклад, О. Олексюк і О. Реброва 
досліджують феномен міжкультурної компетентності. У межах теоретичних узагальнень учені уточнюють поняття «полікультурне освітнє середовище», розуміючи його як «...сукупність культурних, духовних і матеріальних чинників існування і діяльності суб’єктів педагогічного процесу, в яких знаходять відображення культурне різноманіття суспільства $\mathrm{i}$ характер відносин між суб'єктами, що представляють різні етнічні та інші соціальні групи: мовні, конфесійні, гендерні тощо» [12, с.19].

У Іфан спеціально розглядає проблему підготовки майбутніх учителів музики до роботи в умовах полікультурного середовища, яке інтерпретує як таке, що зумовлює«...цілеспрямоване застосування етнічних мистецьких надбань, етнохудожніх цінностей як засобу соціокультурного діалогу, вміння створювати атмосферу взаємопідтримки та поваги між представниками різних національних культур під час музичного навчання та художньо-творчої взаємодії» [16, с. 7].

В основі такої підготовки знаходиться сформована фахова полікультурна компетентність. Вона «...забезпечує вчителю музики ефективність використання етнохудожніх надбань мистецької творчості в педагогічному та соціокультурному процесах, в яких учитель музики виконує функції, зумовлені вимогами діалогу культур різних етнічних груп у контексті національної державної політики» [16, с. 8$]$.

Компаративістський підхід дозволяє здійснювати порівняння художньо-естетичного контенту. Наприклад, під час роботи з китайськими студентам над художньо-образною основою твору варто враховувати, що уявлення китайських студентів щодо естетики можуть бути відмінними від уявлень українських студентів за наявності існуючої іншої системи естетичних категорій.

Так, наприклад, у дослідженні Цзяо Їн застосовано компаративістський підхід саме у процесі фортепіанної підготовки майбутніх учителів музичного мистецтва 3 Китаю. Дослідниця зіставляє різні системи естетичних категорій: європейську, що бере початок 3 філософії античної Греції; східної, що виникала на грунті вчення Конфуція. Дослідниця шукає аналогів категорії «краса». Виявляється, що у східній філософії іiї відповідником є не тільки категорія«ци»(«енергетична субстанція світобудови»), але й «ле» («радість»), «пу» («натуральність») та ін. Саме вони визначені як основні категорії естетики сходу [17, с. 8].

3 огляду на проблему дослідження слід також вказати на полімодальний підхід, який у виконавському процесі спонукає на виявлення різноманітних асоціацій, стимулює полімодальні ресурси виконавського процесу музикантів. Йдеться про такі модуси, як: сприйняття (аудіальне, візуальне), тактильне, кінестетичне, когнітивне. Художньо-образні уявлення, що виникають на основі полімодальних психічних процесів, грунтуються на художньо-образній пам'яті. Вона у музикантів-виконавців є достатньо складним психічним процесом щодо запам'ятовування не лише художньої інформації, яка супроводжується когнітивними мисленнєвими діями, а й емоційними. Емоційна пам'ять $є$ обов'язковим атрибутом музично-виконавського процесу. Вона зберігає відчуття, реагування, переживання, які виявлялися під час роботи над тим або тим твором. Поступово у музиканта формується певний емоційно-образний фонд, який зумовлює художньо-адекватні комплекси інтерпретаційних виконавських ідей. О. Олексюк та О. Реброва у якості ефективного засобу впливу на формування художньо-естетичних уявлень щодо образу твору під час інтерпретації пропонують застосовувати художню метафору, яка розглядається науковцями в контексті педагогіки наративу [19].

На основі полімодального підходу у виконавському процесі реалізується провідний педагогічний принцип: єдність раціональних і емоційних способів освоєння мистецтва. Стосовно означеного принципу Г. Падалка пише, що «сприймання, оцінювання і творення мистецтва в навчальному процесі не можуть відбуватися плідно, якщо не передбачають взаємодії раціональних і почуттєвих аспектів психічного життя учнів» [13, с.79]. Так само і підготовка майбутніх учителів музичного мистецтва повинна базуватись на гармонійності когнітивних та емоційних психічних процесів, що конкретизуємо як принцип гармонізації 
когнітивного та емоційного забезпечення інтерпретації музичних творів. Поступове та цілеспрямоване методичне забезпечення такої гармонізації формує у студентів емоційнокогнітивний досвід, який стає основою художньо-естетичного контенту виконавської інтерпретації музичних творів. Він дозволяє адекватно відчути, осмислити образ-емоцію, настрій-смисл та якісно відтворити їх у виконавському процесі.

Якщо у вокальній підготовці гармонізація когнітивного та емоційного охоплює вербальний та музичний пласти художньої тканини твору, то у фортепіанній підготовці процес гармонізації ускладнюється відсутністю в інструментальних творах вербального компоненту, який власне і $є$ традиційною основою когнітивного. 3 огляду на це актуальним в обгрунтуванні методологічної основи методичного супроводу художньо-естетичного контенту виконавської підготовки стає герменевтичний підхід.

Актуалізуючи значущість герменевтичного підходу в загальному педагогічному контексті та в контексті завдань викладання музики, нами було окреслено його загально-педагогічний i фахово-методичний аспекти. Головним генералізованим завданням як учителя музики, так $\mathrm{i}$ викладача ЗВО є забезпечення: «...адекватного розуміння музичних творів, їх сенсу і змісту згідно композиторському задуму» [9, с. 57]; відповідної художньо-естетичної інтерпретації основної ідеї твору «..враховуючи стильові, жанрові настанови, традиції, в яких ідентифіковані зазначені продукти творчості...» [9, с. 57]; усвідомлення педагогічного потенціалу твору в подальшому (імовірному) педагогічному процесі. Останнє завдання передбачає бачення перспективи застосування художньо-естетичних властивостей твору у вирішенні актуальних педагогічних проблем.

Отже, методологічну основу розробки методичного супроводу становлять полікультурний, компаративістський, полімодальний, герменевтичний наукові підходи. Означені підходи сполучаємо з основними векторами педагогічної спрямованості художньоестетичного контенту виконавської підготовки майбутніх учителів музичного мистецтва.

Першим таким вектором визначаємо художньо-світоглядний. Він спрямований на методичне забезпечення процесу формування художнього світогляду як професійного для майбутніх учителів музичного мистецтва. Методичний супровід спрямований на поетапне засвоєння художньо-світоглядних передумов усіх стилів вокальної, фортепіанної та хорової музики. Розкриття цих аспектів здійснюється як викладачами виконавських дисциплін, так i на заняттях історико-теоретичного циклу. Ефективний художньо-світоглядний потенціал має вибіркова дисципліна «Світова художня культура». Майбутні учителі музики, здобувачі першого (бакалаврського) рівня вищої освіти не здатні самостійно інтегрувати отримані знання, зіставляти художню інформацію, узагальнювати ії на світоглядному рівні. Отже, саме викладачі виконавських дисциплін, що здійснюють освітній процес за індивідуальною формою, мають можливість застосовувати «крос-навчальну мистецьку інтеграцію» (О. Реброва, [14]), що дозволяє «...використовувати знання та досвід, отриманий в одних дисциплінах для більшої результативності засвоєння інших» [14, с.17].

Художньо-естетичний світоглядний потенціал виконавської підготовки майбутніх учителів музичного мистецтва в межах стратегії методичного супроводу ми застосовуємо завдяки методу стимулювання причино-наслідкових зв'язків, що здійснюються за технікою «тут i тепер». Цей метод не передбачає попередню підготовку до індивідуальних виконавських занять, а створює ситуацію проблеми-питання, на яке студент може відреагувати завдяки отриманим знанням з інших дисциплін і таким чином самостійно знайти відповідь шляхом активізації пам'яті або скориставшись інтернет-ресурсами і медіа технологіями. Отже, завдяки методу стимулювання причинно-наслідкових зав'язків у студентів формується здатність моментально знаходити потрібну інформацію задля вирішення конкретних проблем на шляху до самостійності та формування власних художньосвітоглядних переконань. Означений вектор методичного супроводу здійснювався в межах полікультурного та компаративістського підходів. Домінувальним принципом стає активізація художньо-інформаційного пошуку та культурно-кодових змістових порівнянь. 
Другий вектор - культурно-полілоговий - також потребує методичного супроводу, оскільки реалізується в межах художньо-комунікативної полілогової проекції. Художній полілог у музично-виконавській творчості представлений багатогранно: від обміну думками 3 приводу інтерпретації образу, до безпосереднього «озвучування» поліфонічної тканини, що $\epsilon$ його найвищим опосередкованим проявом.

У якості методичного супроводу, який забезпечував культурно-полілоговий вектор, було використано метод створення «комунікативних карт». Під час роботи над будь-яким твором студент отримує завдання: розробити комунікативні карти, що відповідають його уявленням про імовірного співрозмовника. Це може бути слухач, композитор, учень, представник іншої культури, де був створений музичний твір. Для вокального твору це може бути поет, герой, від ім'я якого виконується твір. Для диригентсько-хорового процесу - полілог з усіма учасниками хорового колективу. Занурення в таку діалогову атмосферу розширює художньоестетичні горизонти відповідно до уявлень про твір та його застосування в освітньому процесі. Означений метод застосовувався в межах полікультурного підходу та принципу активізації діалогу культур і художніх свідомостей учасників (реальних та віртуальних) художньо-творчого процесу.

Третій вектор - творчо-розвивальний - застосовується на основі мистецького синтезу когнітивних та емоційних психічних процесів під час прямого або опосередкованого спілкування з творами мистецтва. Йдеться про поступове, пролонговане набуття емоційнокогнітивного досвіду, який важливий в усіх видах виконавства. Уміння відчувати образ твору, адекватно переживати закладену в ньому емоцію відіграє важливу роль під час вирішення педагогічного завдання - вміти завдяки музичному твору викликати відповідні почуття в учнів та осмислити їх. Останнє забезпечується активністю та операційністю художнього мислення, вміннями оперувати образами, музичними інтонаціями, що символізують ті або ті художньо-інформаційні коди. Методичним супроводом цього вектору став метод гармонізації емоційного та інтелектуального, що реалізовувався шляхом виконання поставлених завдань та художньо-емоційних тренінгів персоніфікації: занурення в образ, в емоційний стан та його рефлексія, самооцінювання 3 точки зору художньоестетичних відчуттів. Цей метод застосовувався в контексті герменевтичного та полімодального підходів та принципу гармонійності емоційних і раціональних психічних процесів у художньо-творчій діяльності.

Висновки. Таким чином, визначаючи методичний супровід художньо-естетичного контенту виконавської підготовки майбутніх учителів музичного мистецтва було окреслено доцільність застосування полікультурного, компаративістського, полімодального, герменевтичного наукових підходів. Вони забезпечують на методологічному рівні три базові вектори реалізації художньо-естетичного потенціалу виконавської підготовки майбутніх учителів музичного мистецтва:художньо-світоглядний; культурно-полілоговий; творчорозвивальний. На їх грунті визначено педагогічні принципи: активізації художньоінформаційного пошуку та культурно-кодових змістових порівнянь; активізації діалогу культур і художніх свідомостей учасників (реальних та віртуальних) художньо-творчого процесу; гармонійності емоційних та раціональних психічних процесів у художньо-творчій діяльності.

Відповідно до наукової новизни та значущості отриманих результатів уточнено поняття «художньо-естетичний контент виконавської підготовки», що $\epsilon$ процесом опанування, осмислення та відтворення під час інтерпретації художньої інформації; вона опосередковано міститься у кожному музичному творі і має образний, естетико-смисловий характер, переданий засобами музичної мови.

У якості методичного супроводу художньо-естетичний контенту виконавської підготовки було пропоновано три методи, які мають пролонгований характер застосування, адже вони застосовуються протягом усього періоду навчання на базі першого (бакалаврського) освітнього ступеня, а саме: метод стимулювання пошуку причино-наслідкових зв'язків, що 
передбачає техніку «тут і тепер» та застосування інтернет-ресурсів та медіа технологій; метод гармонізації емоційного та інтелектуального, що передбачає застосування художньоемоційних тренінгів персоніфікації (занурення у відчуття героя), рефлексії та самооцінювання 3 точки зору художньо-естетичних почуттів; метод створення «комунікативних карт» та «художньо-комунікативного поля».

Унікальність означених методів зумовлена тим, що вони можуть бути застосовані на різному музичному матеріалі, різноманітному репертуарі, в усіх різновидах виконавської підготовки. Вони також цілеспрямовано формують емоційно-когнітивний досвід, який стає чинником домінування художньо-естетичного контенту виконавської підготовки майбутніх учителів музичного мистецтва.

\section{Література}

1. Бай, Бінь (2014). Формування звуко-тембральних уявлень майбутніх учителів музики в прочесі фортепіанного навчання (Автореф. дис. канд. пед. наук). Національний педагогічний університет імені М.П.Драгоманова. Київ, 20 с.

2. Ван, Чень (2017). Педагогічні умови формування вокально-виконавського артистизму магістрантів музично-педагогічних навчальних закладів. Наукові записки. Випуск 150. Серія: Педагогічні науки. РВВ КДВУ імені В. Винниченка, 222-227.

3. Воротной, М. В. (2008). Исполнительские и педагогические принципы С. И. Савшинского. (Автореферат дис. канд. искусствоведения). Санкт-Петербург, Российский государственный педагогический университет имени А. И. Герцена. Взято из: http://cheloveknauka.com/v/238321/a?\#?page=1.

4. Демір, М. I. (2016). Формування інтерпретаційної культури в майбутніх учителів музики в nроцесі професійної підготовки. (Автореф. канд.пед.наук). Південноукраїнський національний педагогічний університет імені К.Д.Ушинського. Одеса, 20 с.

5. Завалко, К. В. (2008). Формування музично-виконавської культури майбутнього вчителя музики (скрипаля). Науковий часопис Наџіонального педагогічного університету імені М.П. Драгоманова. Серія 16. Творча особистість учителя: проблеми теорї і практики: Збірник наукових праиь, 8 (18). С. 101-104.

6. Кирчанова, Е. Г. (2003). Педагогические воззрения выдающихся представителей Западноевропейского музыкального искусства ХІХ века в профессиональной подготовке учителя музыки (Автореф. дис. канд. пед. наук). Ур. гос. пед. ун-т. Екатеринбург, 17 с.

7. Лай, Сяоцянь (2017). Культура міжособистісної творчої взаємодії майбутніх учителів музичного мистецтва у процесі вокальної підготовки. Науковий вісник Південноукраӥнського наиіонального педагогічного університету імені К. Д. Ушинського, 4 (117), 40-44.

8. Лі, Ює (2018). Специфіка художньо-смислових уявлень у фортепіанному виконавстві: методичний аспект. Наукові записки Кіровоградського державного педагогічного університету імені Володимира Винниченка. Серія: Педагогічні науки, 167, 203-207.

9. Линенко, А. Ф. (2018). Герменевтичний підхід у педагогіці і його принципи. Науковий вісник Південноукраӥнського національного педагогічного університету імені К.Д. Ушинського, 3 (122), 55-59. DOI: https://doi.org/10.24195/2617-6688-2018-6-9.

10. Мен, Сіан (2018). Художньо-комунікативний досвід майбутніх викладачів вокалу: категоріальний аналіз поняття. Наукові записки [Центральноукраӥнського державного педагогічного університету імені Володимира Винниченка]. Сер. : Педагогічні науки, 167. 195-198. URL: http://nbuv.gov.ua/UJRN/Nz_p_2018_167_48.

11. Мильштейн, Я.И. (1967). Советы Шопена пианистам. М.: Музыка.

12. Олексюк, О., Реброва, О. (2015). Межкультурная компетентность студентов в координатах духовности. The Caucasus, 08, 02. p. 17-21 Tbilisi, Georgia, DOI: 10.15357.

13. Падалка, Г.М. (2008). Педагогіка мистецтва (Теорія і методика викладання мистецьких дисциплін). Київ, Освіта Украӥни. 274 с.

14. Реброва, О. (2017). Крос-навчальна інтеграція когнітивних процесів у виконавському досвіді майбутніх учителів хореографічних та музичних дисциплін. Науковий часопис Нац. пед. ун-ту ім. М. П. Драгоманова. Сер. 14 : Теорія і методика мистецької освіти, 22 (27). Київ, Вид-во НПУ, 1219. http://nbuv.gov.ua/UJRN/. 
15. Ткачук, А. О. (2010). Методика формування художньо-образного мислення студентів у процесі вокального навчання. (Автореф. дис. канд. пед. наук). Національний педагогічний університет імені М. П. Драгоманова, Київ. 21 с.

16. У, Іфан (2012). Методика підготовки майбутніх учителів музики України і Китаю до роботи в умовах полікультурного середовища. (Автореф. дис. канд. пед. наук). Національний педагогічний університет імені М. П. Драгоманова. Київ, 20 с.

17. Цзяо, Їн (2016). Методика естетичного розвитку майбутніх учителів музичного мистеитва в проиесі навчання гри на фортепіано. (Автореф. дис. канд. пед. наук). Національний педагогічний університет імені К. Д. Ушинського, Київ. 20 с.

18. Чжан, Яньфен (2012). Методика вокальної художньо-виконавської підготовки майбутніх учителів музики в університетах України і Китаю. (Автореф. дис. канд. пед. наук). Національний педагогічний університет імені М. П. Драгоманова. Київ, 20 с.

19. Oleksiuk, O., Rebrova, O. (2017). Conceptual Ideas of Narrative Pedagogy in Professional Formation of a Music Art Teacher. Journal of History Culture and Art Research 7(1). Cilt 7, Say1 1 (2018). http://kutaksam.karabuk.edu.tr/index.php/ilk/issue/view/33. DOI: 10.7596/taksad.v7i1.1471.

20. Wang, Yajun (2016). Communicative clusters of conductor and choral training of prospective musical art teacher. Modern Tendencies in Pedagogical education and Science of Ukraine and Israel: the way to integration, 7, 367-374.

\section{Про авторів:}

Линенко Алла Францівна, доктор педагогічних наук, професор, кафедра музичноінструментальної підготовки ДЗ «Південноукраїнський національний педагогічний університет імені К.Д.Ушинського» (Одеса, Україна); ORCID: 0000-0002-2427-0756

Ніколаї Галина Юріївна, доктор педагогічних наук, професор, кафедра музичного мистецтва і хореографії ДЗ «Південноукраїнський національний педагогічний університет імені К.Д.Ушинського» (Одеса, Україна); ORCID: 0000-0001-6751-1209

Левицька Ірина Миколаївна, кандидат педагогічних наук, старший викладач кафедри музичноінструментальної підготовки ДЗ «Південноукраїнський національний педагогічний університет імені К.Д.Ушинського» (Одеса, Україна); ORCID: 0000-0002-3566-2632

\section{Lynenko A. F., Nikolai H. Yu., Levytska I. M. Methodological guidelines for the artistic and aesthetic aspect of teaching performance the future music teachers}

Relevance of the study. The article raises to the issue of ensuring methodological support for teaching performance the future music teachers in the context of their artistic, aesthetic and pedagogical potential. Artistic and aesthetic content of musical works should be comprehended and reproduced through the performer's interpretation. The study unveils the factors that influence superiority of the technical aspect of performance, which makes it impossible to disclose artistic image of musical works qualitatively.

Literature review. Analysis of the recent research shows that the issues of ensuring methodological support for teaching performance the future music teachers cover all its varieties: piano, vocal, conductor, and choral one. It has been considered from different points of view, namely: comprehension of methodological recommendations of the leading musicians-educators of the past; harmonization of emotional and rational in interpreting the musical works; creative development of the attributes of artistic thinking (timbral-auditory, artistic-semantic representations); polycultural and intercultural aspects of performing training, etc.

Purpose. The purpose of the article is to provide methodological guidelines for the artistic and aesthetic aspect of teaching performance the future music teachers taking into account the main vectors of its pedagogical orientation and all professional varieties.

Research methods. Terminological analysis and theoretical generalization have made it possible to clarify the essence of the concepts of "artistic and aesthetic content" and "methodological support". Analysis of scientific sources and generalization of pedagogical experience have shown the expediency of applying such scientific approaches as: polycultural, comparative, polymodal and hermeneutic.

Results. On the basis of extrapolation of certain approaches to the pedagogical strategy of artistic and aesthetic aspect of teaching performance the future music teachers, the basic vectors of its pedagogical orientation are substantiated: artistic-outlook; cultural-polylogue; creative-developmental. 
Discussion. Comparing the current practice, the study defines continuous application of three key pedagogical principles and methods that are used throughout all stages of teaching performance (all its types) students of the first (bachelor) level of education. These methods are as follows: stimulation of cause and effect relationships that involve "here-and-now" techniques and use of Internet resources and media technologies; harmonization of emotional and intellectual which involves application of artistic and emotional trainings of personification (immersion in the feelings of the hero), reflection and self-evaluation in terms of artistic and aesthetic feelings; creation of "communicative charts" and "artistic-communicative field".

Conclusions. The theoretical contribution to Ukrainian and world science includes the refinement of the concept of the "artistic and aesthetic content of teaching performance" that is the process of mastering, comprehending and reproducing during interpretation of artistic information, which is indirectly contained in each musical work and has a figurative, aesthetic and semantic character transmitted by means of musical language; definition of pedagogical principles that become regulators of methodological support of artistic aspect of teaching performance the future music teachers: activation of artistic-informational search and cultural-code content comparisons; intensification of dialogue of cultures and artistic consciousness among the participants (real and virtual) involved in the art-creative process.

Keywords: musical performance training; vocal training; conductor-choral training; emotional-cognitive experience; future teachers of music.

\section{References}

1. Bai, Bin (2014). Formuvannia zvuko-tembralnykh uiavlen maibutnikh uchyteliv muzyky $v$ protsesi fortepiannoho navchannia [Formation of sound-timbre representations of future music teachers in the process of learning piano playing] (Avtoref. dys. kand. ped. nauk). Natsionalnyi pedahohichnyi universytet imeni M.P.Dragomanova. Kyiv, 20 s. [in Ukrainian].

2. Van, Chen (2017). Pedahohichni umovy formuvannia vokalno-vykonavskoho artystyzmu mahistrantiv muzychno-pedahohichnykh navchalnykh zakladiv [Pedagogical conditions for the formation of vocal-performing artistry of master's students of music-pedagogical education institutions]. Naukovi zapysky. Vypusk 150. Seriia: Pedahohichni nauky. RVV KDVU imeni V. Vynnychenka, $222-227$ [in Ukrainian].

3. Vorotnoy, M. V. (2008). Ispolnitelskie i pedagogicheskie printsipy S. I. Savshinskogo [Performing and pedagogical principles of S. I. Savshinskiy] (Avtoreferat dis. kand. iskusstvovedeniya). Sankt-Peterburg, Rossiyskiy gosudarstvennyy pedagogicheskiy universitet imeni A. I. Gertsena. URL: http://cheloveknauka.com/v/238321/a?\#?page=1 [in Russian].

4. Demir, M. I. (2016). Formuvannia interpretatsiinoi kultury v maibutnikh uchyteliv muzyky v protsesi profesiinoi pidhotovky [Formation of interpretive culture in future music teachers in the process of professional training] (Avtoref. kand.ped.nauk). Pivdennoukrainskyi natsionalnyi pedahohichnyi universytet imeni K.D.Ushynskoho. Odesa, 20 s. [in Ukrainian].

5. Zavalko, K. V. (2008). Formuvannia muzychno-vykonavskoi kultury maibutnoho vchytelia muzyky (skrypalia) [Formation of music-performing culture of the future music teacher (violinist)]. Naukovyi chasopys Natsionalnoho pedahohichnoho universytetu imeni M.P. Dragomanova. Seriia 16. Tvorcha osobystist uchytelia: problemy teorii i praktyky: Zbirnyk naukovykh prats, 8 (18). S. 101-104 [in Ukrainian].

6. Kirchanova, Ye. G. (2003). Pedagogicheskie vozzreniya vydayushchikhsya predstaviteley Zapadnoevropeyskogo muzykalnogo iskusstva XIX veka v professionalnoy podgotovke uchitelya muzyki [The pedagogical views of prominent representatives of West European musical art of the XIX century in professional training of the music teacher] (Avtoref. dis. kand. ped. nauk). Ur. gos. ped. un-t. Yekaterinburg, 17 s. [in Russian].

7. Lai, Siaotsian (2017). Kultura mizhosobystisnoi tvorchoi vzaiemodii maibutnikh uchyteliv muzychnoho mystetstva u protsesi vokalnoi pidhotovky [Culture of interpersonal creative interaction of future music teachers in the vocal training process]. Naukovyi visnyk Pivdennoukrainskoho natsionalnoho pedahohichnoho universytetu imeni K. D. Ushynskoho, 4 (117), 40-44 [in Ukrainian].

8. Li, Yuie (2018). Spetsyfika khudozhno-smyslovykh uiavlen u fortepiannomu vykonavstvi: metodychnyi aspekt [Specificity of artistic-semantic representations in piano performance: methodological aspect]. Naukovi zapysky Kirovohradskoho derzhavnoho pedahohichnoho universytetu imeni Volodymyra Vynnychenka. Seriia: Pedahohichni nauky, 167, 203-207 [in Ukrainian].

9. Lynenko, A. F. (2018). Hermenevtychnyi pidkhid u pedahohitsi i yoho pryntsypy [Hermeneutic approach in pedagogy and its principles]. Naukovyi visnyk Pivdennoukrainskoho natsionalnoho 
pedahohichnoho universytetu imeni K. D. Ushynskoho, 3 (122), 55-59 DOI: https://doi.org/10.24195/26176688-2018-6-9. [in Ukrainian].

10. Men, Sian (2018). Khudozhno-komunikatyvnyi dosvid maibutnikh vykladachiv vokalu: katehorialnyi analiz poniattia [Artistic-communicative experience of future vocal teachers: categorical analysis of the concept]. Naukovi zapysky [Tsentralnoukrainskoho derzhavnoho pedahohichnoho universytetu imeni Volodymyra Vynnychenka]. Ser.: Pedahohichni nauky, 167, 195-198. URL: http://nbuv.gov.ua/UJRN/Nz_p_2018_167_48. [in Ukrainian].

11. Milshteyn, Ya. I. (1967). Sovety Shopena pianistam [Chopin's Tips for Pianists]. M.: Muzyka [in Russian].

12. Oleksyuk, O., Rebrova, O. (2015). Mezhkulturnaya kompetentnost studentov v koordinatakh dukhovnosti [Intercultural competence of students in the spirituality coordinates]. The Caucasus, 08, 02, 1721. Tbilisi, Georgia, DOI: 10.15357. [in Russian].

13. Padalka, H. M. (2008). Pedahohika mystetstva (Teoriia i metodyka vykladannia mystetskykh dystsyplin) [Art pedagogy (Theory and methodology of teaching art disciplines).]. Kyiv, Osvita Ukrainy. 274 s. [in Ukrainian].

14. Rebrova, O. (2017). Kros-navchalna intehratsiia kohnityvnykh protsesiv u vykonavskomu dosvidi maibutnikh uchyteliv khoreohrafichnykh ta muzychnykh dystsyplin [Cross-curricular integration of cognitive processes in the performing experience of future teachers of choreographic and music disciplines]. Naukovyi chasopys Nats. ped. un-tu im. M. P. Dragomanova. - Ser. 14: Teoriia i metodyka mystetskoi osvity, 22 (27). Kyiv, Vyd-vo NPU, 12-19. URL: http://nbuv.gov.ua/UJRN/ [in Ukrainian].

15. Tkachuk, A. O. (2010). Metodyka formuvannia khudozhno-obraznoho myslennia studentiv u protsesi vokalnoho navchannia [Methodology of formation of artistic-figurative thinking of students in the process of vocal training] (Avtoref. dys. kand. ped. nauk). Natsionalnyi pedahohichnyi universytet imeni M. P. Dragomanova, Kyiv. 21 s. [in Ukrainian].

16. U, Ifan (2012). Metodyka pidhotovky maibutnikh uchyteliv muzyky Ukrainy $i$ Kytaiu do roboty $v$ umovakh polikulturnoho seredovyshcha [Methodology of preparing future music teachers of Ukraine and China to work in a multicultural environment] (Avtoref. dys. kand. ped. nauk). Natsionalnyi pedahohichnyi universytet imeni M.P.Dragomanova. Kyiv, 20 s. [in Ukrainian].

17. Tsziao, Yin (2016). Metodyka estetychnoho rozvytku maibutnikh uchyteliv muzychnoho mystetstva $v$ protsesi navchannia hry na fortepiano [Methodology of aesthetic development of future music teachers in the process of learning piano playing] (Avtoref. dys. kand. ped. nauk). Natsionalnyi pedahohichnyi universytet imeni K. D. Ushynskoho, Kyiv. 20 s. [in Ukrainian].

18. Chzhan, Yanfen (2012). Metodyka vokalnoi khudozhno-vykonavskoi pidhotovky maibutnikh uchyteliv muzyky $v$ universytetakh Ukrainy $i$ Kytaiu [Methodology of vocal artistic-performing training of future music teachers at universities of Ukraine and China] (Avtoref. dys. kand. ped. nauk). Natsionalnyi pedahohichnyi universytet imeni M.P.Dragomanova. Kyiv, $20 \mathrm{~s}$.

19. Oleksiuk, O., Rebrova, O. (2017). Conceptual Ideas of Narrative Pedagogy in Professional Formation of a Music Art Teacher. Journal of History Culture and Art Research, 7 (1). Cilt 7, Say1 1 (2018). http://kutaksam.karabuk.edu.tr/index.php/ilk/issue/view/33. DOI: 10.7596/taksad.v7i1.1471.

20. Wang, Yajun (2016). Communicative clusters of conductor and choral training of prospective musical art teacher. Modern Tendencies in Pedagogical education and Science of Ukraine and Israel: the way to integration, 7, 367-374.

\section{About the authors:}

Lynenko Alla Frantsivna, Doctor of Pedagogy, Professor, Division of Music and Instrumental Training, K. D. Ushynsky South Ukrainian National Pedagogical University (Odesa, Ukraine); ORCID: 0000-0002-2427-0756

Nikolai Halyna Yuriivna, Doctor of Pedagogy, Professor, Division of Musical Art and Choreography, , K. D. Ushynsky South Ukrainian National Pedagogical University (Odesa, Ukraine); ORCID: 0000-00016751-1209

Levytska Iryna Mykolaivna, Candidate of Pedagogical Sciences (Ph.D.), Senior Lecturer, Division of Music and Instrumental Training, K. D. Ushynsky South Ukrainian National Pedagogical University (Odesa, Ukraine); ORCID: 0000-0002-3566-2632 